\title{
Anne-Çocuk Çiftlerinin Değer Benzerliği: Orta Çocukluk Döneminde Bir İnceleme
}

\section{Value Similarity of Mother-Child Dyads: An Investigation in Middle Childhood}

\author{
Ayşe Vildan Acar-Bayraktar ${ }^{1}$ (D), Zeynep Çakmak ${ }^{1}$ (D), Dilek Sarıtaş-Atalar ${ }^{2}$ (]), \\ Zehra Uçanok ${ }^{3}$ (i)
}

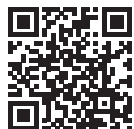

"Yazar Notu: Doç. Dr. İdil IŞıK'a değerler anketini, tez öğrencilerinin tezlerini ve analizlerini paylaşarak çalışmamıza katkıda bulundukları için ve Dr. Öğretim Üyesi Kürşad DEMIRUTKU'ya analizler sırasındaki yardımları için çok teşekkür ederiz.

'Arş. Gör., Hacettepe Üniversitesi Edebiyat Fakültesi, Psikoloji Bölümü, Ankara, Türkiye ${ }^{2}$ Doç. Dr., Ankara Üniversitesi, Dil ve Tarih - Coğrafya Fakültesi, Psikoloji Bölümü, Ankara, Türkiye

${ }^{3}$ Prof. Dr., Hacettepe Üniversitesi Edebiyat Fakültesi, Psikoloji Bölümü, Ankara, Türkiye

ORCID: A.V.A.B. 0000-0001-5769-8524;

Z.Ç. 0000-0003-0457-6835;

D.S.A. $0000-0002-7323-7987$

Z.U. 0000-0003-3953-300X

Sorumlu yazar/Corresponding author: Dilek Sarıtaş-Atalar

Ankara Üniversitesi, Dil ve Tarih - Coğrafya Fakültesi, Psikoloji Bölümü, Ankara, Türkiye

E-posta/E-mail: dsaritas@ankara.edu.tr

Başvuru/Submitted: 30.07 .2020

Kabul/Accepted: 22.12 .2020

Online Yayın/Published Online: 10.08.2021

Citation/Atıf: Acar-Bayraktar, A.V., Çakmak Z., Sarıtaş-Atalar, D., ve Uçanok, Z. (2021). Anne-çocuk çiftlerinin değer benzerliği: Orta cocukluk döneminde bir inceleme. Psikoloji Çalışmaları - Studies in Psychology, 41(2), 521-548.

https://doi.org/10.26650/SP2020-0109
ÖZ

Değerler ve çocukların değer kazanımı kapsamında yürütülen yakın zamanlı gelişim psikolojisi araștırmaları, orta çocukluğun ilk yıllarında bile çocukların değer önceliklerinin oluşabildiğini göstermiştir. Sosyalleştirme sürecinin birincil aktörü olan ebeveynler, çocuklarının değer gelişiminde önemli bir role sahiptir. Bu çalışmada, anne-çocuk çiftlerinin Schwartz'ın 10 değer tipi açısından ne derece benzerlik gösterdiği incelenmiştir. Bu amaçla, Ankara'da yaşayan yaşları 6 ile $11($ Ort. $=8.5, S S=1.23)$ arasında değişen ilkokul 1., 2., 3. ve 4. sınıfa devam eden 172 öğrenci ve anneleri çalışmaya dahil edilmiştir. Annelerin değerlerini ölçmek amacıyla Portre Değerler Anketi, çocukların değerlerini ölçmek amacıyla ise Çocuklar için Resme Dayalı Değerler Taraması kullanılmıştır. Elde edilen bulgular anneler için başarl, güvenlik ve özyönelim değerleri ile özgenişletim ve muhafazacılık üst değerlerinin önemli olduğunu göstermiştir. Buna karş1lık, çocuklar için geleneksellik, iyilikseverlik ve evrenselcilik değerleri ile özaşkınlık ve muhafazacılık üst değerlerinin öncelikli değerler olduğu bulunmuştur. Ayrıca anne-çocuk çiftlerinin değerlerinin genel olarak düşük benzerlik gösterdiği ve değer tiplerine ait öncelik sıralamalarının birbirlerinden farklılaştığı görülmüştür. Bunun yanı sıra, araştırma bulguları anne-çocuk çiftlerinin değer benzerliği ile annenin eğitim düzeyi ve toplam aylık gelirin ilişkili olduğunu ve bu ilişkilerin çocuğun yaşına göre farklılaştığı ortaya koymuştur. Annenin eğitim düzeyi ve toplam aylık gelir küçük yaş grubundaki anne-çocuk çiftlerinin değer benzerliği ile ilişkili değilken büyük yaş grubundaki anne-çocuk çiftlerinin değer benzerliği ile negatif yönde ilişkilidir. Benzer şekilde, annenin eğitim düzeyi ve toplam aylık gelir ile anne-çocuk çiftlerinin değer benzerliği arasındaki ilişkinin çocuğun cinsiyetine göre de farklılaştığı görülmüştür. Annenin eğitim düzeyi ve toplam aylık gelir anne-erkek çocuk çiftlerinin değer benzerliği ile ilişkili değilken anne-kız çocuk çiftlerinin değer benzerliği negatif yönde ilişkilidir. Sonuç olarak, elde edilen bulguların değerlerin nesiller arası aktarımı konusunda bilgi sağlayabileceği ve okullardaki değerler eğitimi ile ilgili müfredatın düzenlenmesinde yol gösterici ipuçları taşıyabileceği düşünülmektedir.

Anahtar Kelimeler: Schwartz'ın Değer Kuramı, orta çocukluk, değer kazanımı, değer benzerliği 


\begin{abstract}
Recent developmental psychology studies conducted within the context of values and children's value acquisition have shown that even during the early years of middle childhood, children's value priorities can occur. Parents, who are the primary actors in the socialization process, play an important role in the value development of their children. In this study, the similarities between mother-child dyads in terms of the 10 value types of Schwartz were examined. For this aim, a total of 172 mothers and their children between ages $6-11(M=8.5, S D=1.23)$ years attending 1 st, 2nd, 3rd, and 4th grade in primary schools in Ankara were included in this study. The Portrait Value Questionnaire was used to assess mothers' values, and the Picture-Based Value Survey was used to assess children's values. The findings showed that mothers gave priority to the values of achievement, security, and self-direction and high-order values of self-enhancement and conservation. In contrast, it was found that children gave priority to the values of tradition, benevolence, and universality and higher-order values of self-transcendence and conservation. Furthermore, it was seen that the values of the mother-child dyads had lower similarities, and the order of the priority of the value types differed from each other. In addition, our findings revealed that there were significant relationships among the mother's education, total monthly income, and mother-child value similarity, which varied according to the age of the child. While the mothers' education and total monthly income were not associated with the mother-younger child value similarity, these were negatively associated with the mother-older child value similarity. Similarly, it was observed that the relationship among the mothers' education, total monthly income, and mother-child value similarity also varied according to the gender of the child. While the mothers' education and total monthly income were not associated with the mother-son value similarity, these were negatively associated with the mother-daughter value similarity. In conclusion, it is thought that these findings can provide information about the intergenerational transfer of values and provide guiding clues for the regulation of curriculum related to value education in schools.
\end{abstract}

Keywords: Schwartz's Theory of Values, middle childhood, value acquisition, value similarity

\title{
EXTENDED ABSTRACT
}

Human values have been one of the key issues in the social sciences where individuals' attitudes and behaviors are examined. Values can be defined as relatively stable beliefs that determine the individual and social desirability of goals and behaviors (Schwartz, 1992). This research is based on Schwartz's (1992) theory of values, which is currently the most used theory in the social sciences. Socialization is the process by which the values, expectations, and beliefs of a society are transferred to the next generations and in which the parents and children mutually interact (Grusec \& Goodnow, 1994; Kuczynski, Marshall, $\&$ Schell, 1997). The value similarity of parents and children is considered an implication of this value socialization process (Grusec \& Davidov, 2007). It has been indicated that there are significant associations between parent-child value similarity and several different factors such as the socioeconomic level of parents, parenting behaviors, age, and the gender of the child (Hitlin, 2006). In middle childhood, during cognitive and socioemotional development, children gain the ability to take the other's perspective, and so they may have a greater priority toward specific other-oriented values (Döring, Blauensteiner, Aryus, Drögekamp, \& Bilsky, 2010). Therefore, examining mother-child value similarity in middle childhood is an 
interesting topic to research because it is important to understand the effect of increased cognitive skills and reveal this developmental pattern. Starting from this point of view, this study aims to evaluate the similarity between mother-child dyads in terms of the 10 value types of Schwartz and the associations between this similarity and socioeconomic factors in middle childhood.

\section{Method}

A total of 172 mothers $(M=37.31, S D=4.75)$ and their children between ages $6-11$ years $(M=8.5, S D=1.23)$ attending $1 \mathrm{st}, 2 \mathrm{nd}, 3 \mathrm{rd}$, and 4 th grade in primary schools in Ankara participated in the study. The Portrait Value Questionnaire (Schwartz et al., 2001) was used to assess mothers' values, and the Picture-Based Value Survey (Döring et al., 2010) was used to assess children's values.

\section{Results}

The results showed that the mothers gave priority to the values of achievement, security, and self-direction and high-order values of self-enhancement and conservation. Moreover, it was found that the children gave priority to values of tradition, benevolence, and universalism and higher-order values of self-transcendence and conservation.

The findings showed that there were significant mean differences in value types between the mothers and the children. It was seen that when the mothers had higher scores of power, hedonism, self-direction, universalism, benevolence, and conformity, the children had higher scores of tradition. Furthermore, it was found that the values of the mother-child dyads had lower similarities, and the order of the priority of the value types differed from each other. The results revealed that there were significant relations among the mother's education, total monthly income, and mother-child value similarity. These relations varied according to the age and gender of the child. The mothers' education and total monthly income were negatively associated with both mother-older child value similarity and mother-daughter value similarity.

\section{Discussion}

In this study, it was found that while the highest order value types for mothers were achievement, security, and self-direction, the highest order value types for children were tradition, benevolence, and universalism. It was revealed that the mothers' and the children's value priorities differed from each other, and the values of the mother-child dyads had lower similarities. This result may be explained by the fact that while young and middle adults 
give more importance to self-oriented values consistent with their developmental goals, children give more importance to other-oriented values as a result of their socio-cognitional development in middle childhood. Furthermore, it was seen that the mothers' education and total monthly income were significantly related to mother-child value similarity. These were also negatively related to mother-older child value similarity and mother-daughter value similarity. Mothers of a lower socioeconomic level can be more authoritarian and harsher about the socialization of values for older children. Moreover, they expect girls to adapt to and obey their values by adopting a socialization process according to traditional gender norms.

The findings obtained from this research should be evaluated within the limitations of the study. Future longitudinal studies can examine the value development of children and the pattern of parent-child value similarities over time. In future studies, it will be important to address the role of peers and teachers in the value socialization process in middle childhood. Furthermore, the study was conducted with mother-child dyads. Studies with father-child dyads may reveal insightful information in terms of value similarity, and future studies can be conducted with the participation of both parents. Finally, it is thought that repeating the study with a more representative sample in terms of education and income level will increase the generalizability of the findings.

The present research is the first study to examine the value similarities of mother-child dyads in middle childhood in Turkey. In conclusion, it is thought that the results of this study can guide professionals in studying value education. Consequently, these findings can provide information about the intergenerational transfer of values. 
Değerler din, felsefe ve ekonomi gibi birçok disiplinde olduğu gibi bireylerin tutumlarının ve davranışlarının incelendiği davranış bilimleri alanında da önemle ele alınan temel konulardan birisi olmuştur. Değerler en geniş anlamda hedef ve davranışların bireysel ve toplumsal olarak istenirliğini belirleyen görece istikrarlı inançlar şeklinde tanımlanabilmektedir (Schwartz, 1992; Schwartz ve ark., 2001). Bireyler içinde bulundukları toplumun ve kültürün değerlerini benimseyerek, bunları bireysel ve toplumsal düzeydeki muhakeme ve seçimlerinde bir ölçüt olarak kullanmaktadırlar (Kuşdil ve Kağıtçıbaşı, 2000). Buna ek olarak, değerler sosyalleşme sürecinde kazanılan ve davranışları doğrudan güdüleyen hiyerarşik yapılardır (Grusec ve Davidov, 2007; Schwartz, 1992). Çocukların ahlaki değerleri, sosyal normları ve davranış standartlarını düşünüldügünden daha erken anlayabildikleri; erken çocukluk döneminden itibaren değerlerin hangi amaçlara uygun olarak ortaya çıktığını kavrama ve değerleri ilişkilerinde kullanma eğiliminde oldukları görülmüştür (Thompson, Meyer ve McGinley, 2006). Orta çocukluk dönemi ise perspektif alma ve özdüzenleme gibi bilişsel (Santrock, 2012) ve empati gibi sosyo-duygusal becerilerin (Bensalah, Stefaniak, Carre ve Besche-Richard, 2016) olgunlaştı̆̆ 1 bir dönemdir. Söz konusu becerilerin gelişmesiyle orta çocukluk döneminde, ebeveyn ve akranlar gibi sosyalleşme aktörleri ile kurulan ilişkilerde kendi ya da diğeri odaklı olma motivasyonları doğrultusunda çeşitli değerlerin belirgin olarak önem kazandığı bilinmektedir (Uzefovsky, Döring ve Knafo-Noam, 2016). Bu gelişimsel örüntüyü ortaya koymak, artan bilişsel becerilerinin ve gelişimsel açıdan ilk kez sisteme giren diğer sosyalleştirme aktörlerinin etkisini anlamak açısından, orta çocukluk döneminde değerlerin incelenmesini oldukça önemli kılmaktadır. Ancak ilgili alan yazın incelendiğinde, çocukların değer kazanımı ve ebeveynleriyle değer benzerliğini ele alan çalışmaların görece daha yakın zamanlı olduğu ve daha ağırlıklı olarak ergenlik ve sonrasını kapsayan gelişim dönemlerine odaklandığı dikkati çekmektedir (Akarslan Esen ve Cesur, 2015; Barni, Ranieri, Scabini ve Rosnati, 2011; Demirutku, 2007). Bu bilgilerden hareketle mevcut çalışmanın temel amacı orta çocukluk döneminde anneler ve çocuklarının değerlerine ilişkin örüntüyü ortaya koymaktır. Bu amaç çerçevesinde çalışma, psikoloji ve ilgili disiplinlerde öne çıkan Schwartz'ın (1992) değer kuramı temel alınarak gerçekleştirildiği için öncelikle kuram kısaca tanıtılacaktır.

\section{Schwartz'ın Değer Kuramı}

Schwartz (1992) insani değerleri evrensel gereksinimlerin bilişsel temsili olarak değerlendirmiş, içerik ve yapısal olarak kültürlerarası geçerliği olan evrensel 10 değer tipi 
tanımlamıştır. Bunlar güç, başarı, hazcılık, uyarılım, özyönelim, evrenselcilik, iyilikseverlik, geleneksellik, uyma ve güvenliktir. Her bir değer tipinin altında yatan temel bir motivasyonel içgüdü ve amaç bulunmaktadır (Bkz. Tablo 1).

Tablo 1. Değerler ve Temel Motivasyonları (Schwartz, 1992)

\begin{tabular}{|c|c|c|c|}
\hline Değerin türü & Tanımı & Değer örnekleri & Odağı \\
\hline Evrenselcilik & $\begin{array}{l}\text { Bütün insanların refahını ve doğayı } \\
\text { düşünme, önemseme ve koruma }\end{array}$ & $\begin{array}{l}\text { Eşitlik, bilgelik, doğa ile iç } \\
\text { içe olma, sosyal adalet }\end{array}$ & Diğeri odaklı \\
\hline İyilikseverlik & $\begin{array}{l}\text { Yakın olduğu kişilerin iyiliğini } \\
\text { düşünme ve koruma }\end{array}$ & $\begin{array}{l}\text { Yardımseverlik, dürüstlük, } \\
\text { affetme, sorumluluk }\end{array}$ & Diğeri odaklı \\
\hline Geleneksellik & $\begin{array}{l}\text { Geleneksel kültüre veya dinin } \\
\text { sağladığı gelenek ve düşüncelere } \\
\text { sayg1, bağlılık ve kabul }\end{array}$ & $\begin{array}{l}\text { Geleneklere saygı, } \\
\text { dindarlık, mütevazılık }\end{array}$ & Diğeri odaklı \\
\hline Uyma & $\begin{array}{l}\text { Başkalarını üzen ya da zarar verecek } \\
\text { ve sosyal beklentileri veya normları } \\
\text { ihlal edebilecek eylem, eğilimler ve } \\
\text { dürtülerin kısıtlanması. }\end{array}$ & $\begin{array}{c}\text { İtaat, özdisiplin, } \\
\text { ebeveynleri ve aile } \\
\text { büyüklerini onure etme }\end{array}$ & Diğeri odaklı \\
\hline Güvenlik & $\begin{array}{l}\text { Toplumun, ilişkilerin ve benliğin } \\
\text { güvenliği, uyumu ve istikrarı }\end{array}$ & $\begin{array}{l}\text { Ulusal güvenlik, aile } \\
\text { güvenliği, aidiyet, sağlık, } \\
\text { sosyal düzen }\end{array}$ & Diğeri odaklı \\
\hline Güç & $\begin{array}{l}\text { Sosyal statü ve prestij, insanları ve } \\
\text { kaynakları kontrol etme ve yönetme }\end{array}$ & $\begin{array}{l}\text { Sosyal güç, zenginlik, } \\
\text { otorite, }\end{array}$ & Kendi odaklı \\
\hline Başarı & $\begin{array}{l}\text { Sosyal standartlara uygun şekilde } \\
\text { kişisel başarı gösterme }\end{array}$ & $\begin{array}{l}\text { Hırs, etkileyici, becerikli, } \\
\text { başarılı, kendine sayg1lı } \\
\text { olma }\end{array}$ & Kendi odaklı \\
\hline Hazcılık & $\begin{array}{l}\text { Bireyin keyif alması ve duygusal } \\
\text { açıdan memnun hissetmesi }\end{array}$ & $\begin{array}{l}\text { Keyif, yaşamdan zevk } \\
\text { alma }\end{array}$ & Kendi odakl1 \\
\hline Uyarılım & $\begin{array}{c}\text { Yaşamda heyecan duyma, yenilik } \\
\text { arama ve meydan okuma }\end{array}$ & $\begin{array}{l}\text { Heyecan verici ve } \\
\text { değişken hayat, cesaret }\end{array}$ & Kendi odaklı \\
\hline Özyönelim & $\begin{array}{c}\text { Bağımsız düşünce ve eylem seçme, } \\
\text { yaratma, keşfetme }\end{array}$ & $\begin{array}{l}\text { Özgürlük, yaratıcılık, } \\
\text { bağımsızlık, kendi } \\
\text { hedeflerini seçme }\end{array}$ & Kendi odaklı \\
\hline
\end{tabular}

Schwartz'ın kuramı (Schwartz, 1992; Schwartz ve ark., 2001) değerler arasındaki dinamik ilişkileri de açıklamaktadır. Bir başka deyişle, herhangi bir değere uygun olan bir davranışın diğer bir değerle çatışması fakat bir başka değer ile uyuşan sonuçlarının olması temelinde örtüşme ya da ters düşme durumuna dayanarak döngüsel bir model öne sürmektedir (Bkz. Şekil 1). 


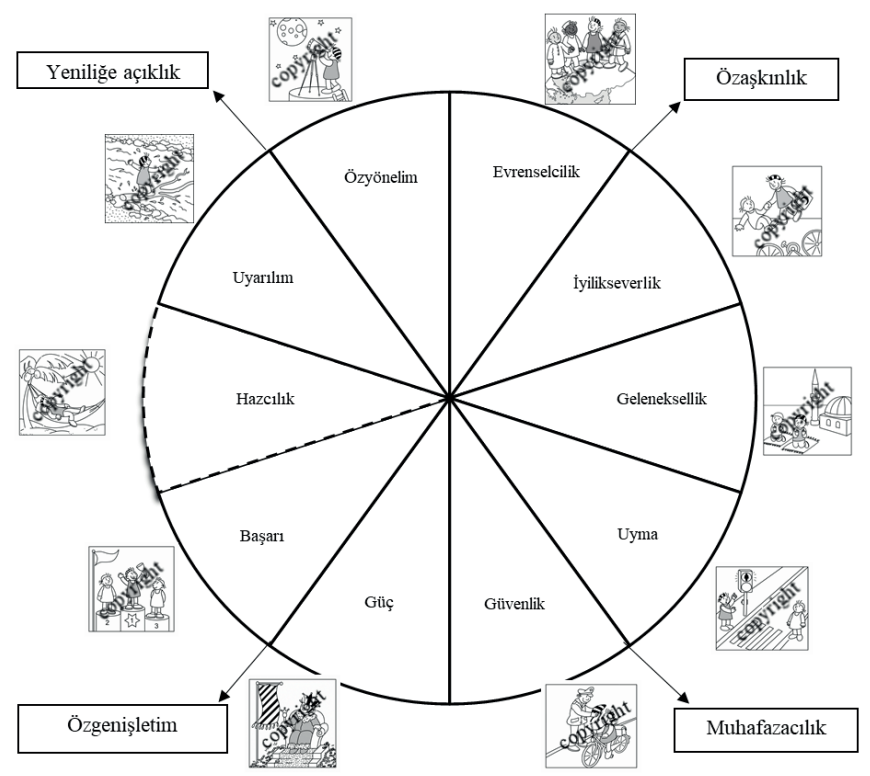

Şekil 1. Schwartz'nn dairesel değer modeli (Schwartz, 1992) ve Resme Dayalı Değerler Taraması'nda kullanılan örnek resimler (Döring ve ark., 2010)

Modelde motivasyonel amacı açısından birbiriyle örtüşen değerler yan yana gösterilirken, birbiriyle ters düşen değerler karş1lıklı gösterilmiştir. Bunun yanı sıra, 10 değer birbirine dikey çift kutuplu iki boyutta değerlendirilmiştir (Bkz. Tablo 1). Bunlardan birincisi yeniliğe açıklıktan (uyarılım ve özyönelim) muhafazacılığa (uyma, geleneksellik ve güvenlik) uzanan boyut, diğeri ise özgenişletimden (güç ve başarı) özaşkınlığa (evrenselcilik ve iyilikseverlik) uzanan boyuttur. Bu boyutlara göre 10 değer dört boyutta gruplanabilmektedir. Hazcılık değeri ise bu dört boyutta yer almamakla birlikte yeniliğe açıklık boyutundaki değerlere yakındır. Schwartz (1992) bu dört boyutu, üst seviye değerler olarak kavramsallaştırmaktadır.

\section{Değerlerin Sosyalleştirilmesi Kazanımı}

Sosyalleştirme toplumun değerlerini, beklenti ve inançlarını gelecek nesillere aktarmayı amaçlayan, çocuğun söz konusu değerleri içselleştirmesini yani herhangi bir diş kontrol ya da müdahale olmaksızın kabul etmesini sağlayan ve ebeveyn ile çocuk arasındaki etkileşime dayanan çift yönlü bir süreç olarak ele alınmaktadır (Grusec ve Goodnow, 1994). Bu süreçte ebeveyn ve çocuk karşılıklı etkileşim içerisinde olan aktif ajanlardır (Kuczynski, Marshall ve Schell, 1997). Ebeveyn-çocuk arasındaki karşılıklı 
olumlu ilişkinin erken kurulması (Kochanska, Aksan, Prisco ve Adams, 2008) çocuğun ebeveyninin benimsediği değerleri içselleştirmesini sağlamakta ve çocuğun öz düzenlemesini artırmaktadır. Benzer şekilde, ebeveynin disiplin ve otorite kullanımı ne kadar uygunsa yani açıklama yapmaya ve çocuğun bakış açısını almaya yönelik ise (Grusec ve Goodnow, 1994) ve ebeveyn kabulü yüksek ise (Demirutku, 2007) çocuğun değerleri içselleştirmesi ve öz düzenlemesi o derecede artmaktadır. Buna karşın, ebeveyn kabulü düşük ve kontrolü yüksek olduğunda ise çocuğun değerleri içselleştirmesi azalmaktadır (Demirutku, 2007).

Ebeveynlerin çocuklarının içinde bulundukları gelişim dönemini dikkate alması değer kazanımında önemlidir. Çocukluk dönemi boyunca değer gelişiminde yaşla birlikte diğeri yönelimli değerlerden, birey yönelimli değerlere doğru bir değişim görülmektedir (örn., Bilsky ve ark., 2013). Bu gelişimsel değişikliklerle tutarlı şekilde, Tulviste (2013) farklı gelişim dönemlerinde ebeveynlerin de çocuklarında farklı değerlerin kazanımına öncelik verdiklerini göstermiştir. Örneğin, orta çocukluk döneminde çocuğa sahip olan annelerin ailede geleneksel değerlerin (terbiyeli olma, diğerlerine saygı) kazanımına daha çok önem verdiklerini; buna karşın, ergenlerin annelerinin ise otonomi ile ilişkili değerlerin (hırslı olma, kararlılık, sağlıklı bir yaşam tarzı) kazanımına daha fazla önem verdiklerini ortaya koymuştur.

Okul öncesi, orta ve ileri çocukluk dönemlerinde yürütülen çalışmalardan elde edilen bulgular erken yaşlardan itibaren değer yapılarının farklılaşmaya başladığını göstermiştir (Bilsky ve ark., 2013; Çakmak, Acar-Bayraktar ve Sarıtaş-Atalar, 2018; Döring, 2010). Bunun yanı sıra, farklı değerlerin bazı gelişim dönemlerinde daha çok ön plana çıktığı görülmektedir (Döring, Daniel ve Knafo-Noam, 2016). Küçük çocuklar diğerlerinin bakış açısını göz önünde bulundurma ve diğeri yönelimli açıklamaları anlamada zorlanırken, yedi yaşından itibaren çocuklar bu becerileri kazanabilmektedirler (Döring, Blauensteiner, Aryus, Drögekamp ve Bilsky, 2010). Ayrıca bu yaştan itibaren çocuklar diğerlerinin niyetlerinin de önemli olduğunu göz önünde bulundurarak eylemin sonucunu değerlendirmeye ve diğerlerinin inanç ve düşüncelerinin de önemli olduğunu anlamaya başlamaktadırlar (Daniel, Benish-Weisman, Sneddon ve Lee, 2020). Dolayısıyla, orta çocukluk döneminden itibaren diğeri yönelimli değerleri anlayıp içselleştirmede artış gözlenmektedir (Grusec ve Goodnow, 1994). Bu artışa paralel olarak, orta çocukluk döneminde çocukların geleneksellik, iyilikseverlik ve evrenselcilik değerleri ile özaşkınlık ve muhafazacılık üst değerlerine daha fazla önem verdikleri gösterilmiştir 
(Daniel ve ark., 2020; Döring ve ark., 2010; Özvanlıgil, 2013; Petersen, 2013). Buna ek olarak, Cieciuch, Davidov ve Algesheimer (2016) yedi ile 11 yaşları arasındaki çocuklarla boylamsal olarak yürüttükleri çalışmada, orta çocukluktan ergenliğe geçiş sürecinde muhafazacılık ve özaşkınlık değerlerinin yaşla beraber azaldığını; yeniliğe açıklık ve özgenişletme değerlerinin ise arttı̆̆ını bulmuşlardır.

Farklı yaş gruplarını ele alan çalışmalar, yaş ilerledikçe çocukların daha iyi ayrıştırılmış değer yapılarına sahip olduğunu ortaya koymuştur (Bubeck ve Bilsky, 2004; Petersen, 2013). Ergenlik döneminden itibaren, değer gelişiminin ilerlemesi ile birlikte, yetişkinlerden elde edilen örüntüye benzer şekilde ayrışmış bir değer yapısına sahip olunduğu görülmüştür (Barni, Ranieri ve Scabini, 2012; Knafo ve Schwartz, 2009). Buna paralel olarak, ergenlik dönemi ile birlikte değer öncelikleri de farklılaşmaya başlamaktadır. Örneğin, Bilsky ve arkadaşları (2013) 10 yaşından küçük çocukların iyilikseverlik, evrenselcilik ve güvenlik gibi diğeri odaklı değerlere daha fazla önem verdiğini, 10 yaşından büyük olan çocukların ise iyilikseverlik ve evrenselcilik gibi diğeri odaklı değerlere önem vermelerinin yanı sıra hazcılık gibi kendi odaklı değerlerin de öncelikli değerleri arasında yer almaya başladığını göstermişlerdir. Türkiye'de yürütülen bir çalışmada, lise öğrencilerinin evrenselcilik değerinin yanı sıra kendi odaklı değerlerden olan özyönelim değerine daha çok, geleneksellik ve uyma değerlerine ise daha az önem verdikleri ortaya konulmuştur (Sesli ve Demir Başaran, 2016). Lise ve üniversite öğrencileri ile yürütülen bir başka çalışmada, özyönelim değerinin lise öğrencilerinin öncelik sıralamasında ikinci sırada yer aldığı, üniversite öğrencileri için ise en önemli değer olduğu görülmüştür. Buna ek olarak, lise öğrencilerine kıyasla üniversite öğrencilerinin kendi odaklı bir değer olan hazcılık değerini önem sıralamasında daha üste yerleştirdikleri görülmüştür (Demirutku, 2007). Genç ve ileri yetişkinlerin karşılaştırıldığı çalışmalar ise genç yetişkinlerin yeniliğe açıklık ve özgenişletim üst değerlerine, ileri yetişkinlerin ise muhafazacılık üst değerine daha fazla önem verdiğini ve yetişkinlik döneminde yaşın ilerlemesiyle birlikte, diğeri yönelimli değerlere daha fazla önem vermeye başladıklarını göstermiştir (Tulviste, Kall ve Rämmer, 2017; van Herk ve Poortinga, 2012). Bunun yanı sıra, yetişkinlik döneminde önce eş seçme ve aile kurma; sonrasında yaşın ilerlemesiyle birlikte sosyal ilişkilerden keyif alma gibi konularda yansımasını gördüğümüz etkileşim değerleri (interactive values) doğrusal olarak artarken, heyecan ve var oluş değerleri ergenlik yılları ile ileri yetişkinlik yılları arasında ters U bir değişim göstermekte, geleneksellik gibi norm değerleri ise ergenlikten ileri yetiş- 
kinlik yıllarına geçişte U şekilli bir değişim sergilemektedir (Gouveia, Vione, Milfont ve Fischer, 2015). Özetle, bu doğrultuda yürütülen çalışmalar bireylerin değer önceliklerinin yaşla birlikte eğrisel olarak değiştĭgini, çocukların diğeri yönelimli değerlerden kendi yönelimli değerlere doğru bir değişim yaşadığını, ergenliğe geçişle birlikte yetişkinlere benzer şekilde bireysel değerlere daha fazla önem vermeye başladıklarını ve yetişkinlik döneminde yaşın ilerlemesiyle birlikte ise diğer odaklı değerlere daha fazla önem vermeye başladıklarını ortaya koymuştur. Bu bakış açısından hareketle, çalışmada Türkiye'de yaşayan çocukların orta çocukluk döneminde o yaş grubuna uygun değerlere sahip olup olmadıkları ile anneler ve çocuklarının değerlerinin benzerliğini incelemek amaçlanmıştır.

\section{Ebeveynler ve Çocukların Değer Benzerliği}

Ebeveynler ve çocuklarının değer benzerliği sosyalleştirme sürecinin bir çıktısı olarak ele alınmaktadır (Grusec ve Davidov, 2007; Schwartz, 1992). Ebeveynler ve çocuklarının değerlerinin ne kadar benzediğini farklı yaş gruplarında çalışmak oldukça önemlidir, çünkü ilgili alan yazında yürütülen çalışmalar farklı yaş dönemlerinde benzerlik örüntüsünün farklılaştığını göstermektedir. Örneğin, yedi ile dokuz ve altı ile on bir yaşları arasındaki çocuklar ve ebeveynleriyle yürütülen iki farklı çalışmada ebeveynler ve çocuklarının orta düzeyde değer benzerliğine sahip oldukları ortaya konmuştur (Döring, Makarova, Herzog ve Bardi, 2017). Ebeveynler ve çocuklarının değer benzerliğinin erken ve orta çocukluk döneminde ergenlik ve sonrası döneme kıyasla daha az çalışıldığı dikkati çekmektedir. Bunun sebebinin ölçüm aracı kaynaklı olabileceği düşünülmektedir. Erken ve orta çocukluk döneminde değer önceliklerinin incelenebilmesi için Resme Dayalı Değerler Taraması (RDDT) kullanılmaktadır (Döring ve ark., 2010). RDDT görece yeni, çocuklarla 20-25 dakikalık uygulama gerektiren, anket kullanımına kıyasla zaman açısından maliyetli bir ölçüm aracıdır.

Orta çocukluk döneminde ebeveyn - çocuk değer benzerliğinin çalışılması oldukça önemlidir, çünkü çocuklar bu dönemde ebeveynleri dışında çevrelerindeki diğer kişilerle (örn., akranları ve öğretmenleri) sosyal etkileşimlere girerler (Uzefovsky ve ark., 2016). Bunun yanı sıra, artan bilişsel becerileri sayesinde daha az kendi odaklı daha fazla diğeri odaklı değerlere sahip olurlar (Döring ve ark., 2010; 2016; Grusec ve Goodnow, 1994). Değer kazanımı sürecinde çocuğun artan bilişsel becerileri ile birlikte ebeveyn değerleri dişında diğer çevresel etkenlerden de etkilenmesi, çocuğun ebeveyn değerlerinden uzaklaşması ve kendi değerlerini keşfetmesi ile sonuçlanabilir. Ancak bu konuda yürütülen çalışmalar oldukça sınırlıdır. 
Ebeveynler ve ergenlerin değer benzerliğine ilişkin bilgi birikimi ise görece daha zengindir. Örneğin, bir çalışmada 15 ile 19 yaşları arasındaki ergenler ile ebeveynlerinin değerlerinin benzer olduğu ortaya koyulmuştur (Barni ve ark., 2011). Türkiye' de yürütülmüş olan iki çalışmadan birinde, üniversite öğrencileri ve ebeveynlerinin benzer değer önceliklerine sahip olduğu (Akarslan Esen ve Cesur, 2015), lise ve üniversite öğrencilerinin yer aldığı diğer çalışmada ise lise öğrencileri ve üniversite öğrencilerinin ebeveynleriyle benzer değerlere öncelik verdikleri (Demirutku, 2007) görülmüştür. Bir başka çalışmada ise ergenler ve ebeveynlerine kıyasla, beliren yetişkinlik dönemindeki gençler ve ebeveynlerinin değerlerinin daha benzer olduğu gösterilmiştir (Barni, Alfieri, Marta ve Rosnati, 2013). Dolayısıyla, ergenlik döneminden ilk yetişkinlik yıllarına doğru gidildikçe, ebeveynler ve çocuklarının değerlerinin daha benzer olduğu görülmektedir. $\mathrm{Bu}$ örüntü, beliren yetişkinlik döneminden itibaren aile ilişkilerinin doğasında meydana gelen değişim ve dönüşüm nedeniyle, ebeveynlerin değerlerini benimsemeye daha istekli olunmasıyla ilişkili olabilir. Buna ek olarak, beliren yetişkinlik döneminden itibaren bireylerin toplumda ebeveynleriyle ortak statülerde yer almasından dolayı benzer değer kalıp yargılarına sahip olmalarıyla da açıklanabilmektedir (Barni ve ark., 2013 ; 2012).

Ebeveynlerin eğitim durumları, meslekleri ve gelirleri üzerinden belirlenen sosyoekonomik düzeyin ebeveyn ve çocuğun değer öncelikleri ile ilişkisi olduğu görülmüştür (Cashmore ve Goodnow, 1986; Hitlin, 2006). Genel olarak bakıldığında, düşük sosyoekonomik düzeyin uyma değerine öncelik vermeyle, yüksek sosyoekonomik düzeyin ise yeniliğe ve genel olarak uyum ve değişime açıklık değerine öncelik vermeyle ilişkili bir faktör olduğu görülmüştür (Cashmore ve Goodnow, 1986). Değer önceliğini eğitim düzeyi açısından ele alan bazı çalışmalarda bireylerin eğitim düzeyleri arttıkça özyönelim, uyarılım ve yeniliğe açıklık değerlerine öncelik verdikleri, eğitim düzeyleri azaldıkça uyma ve geleneksellik değerlerine daha öncelik verdikleri ortaya konmuştur (Prince-Gibson ve Schwartz, 1998; Schwartz ve arkadaşları, 2001). Sosyoekonomik düzey ile çocukların değer öncelikleri arasındaki ilişkinin incelendiği Uzefovsky ve arkadaşlarının (2016) çalışmasında, annenin eğitim düzeyi ile yeniliğe açıklık değeri arasında pozitif yönde ilişki bulunmuştur. Bir diğer deyişle annelerin eğitim düzeyi arttıkça, çocukları yeniliğe açıklık değerine daha fazla öncelik vermişlerdir. Türkiye'de yürütülen bir çalışmada ise düşük sosyoekonomik düzeyden gelen çocukların muhafazacılık değerine daha fazla öncelik verdikleri, buna karşın yüksek sosyoekonomik düzeydeki çocuk- 
ların yeniliğe açıklık değerine öncelik verdikleri görülmüştür (Özvanlıgil, 2013). Tüm sonuçlar birlikte değerlendirildiğinde, sosyoekonomik düzeyin hem ebeveynlerin hem de çocukların değer önceliği ile ilişkili bir faktör olduğu görülmektedir. Ancak alan yazında sosyoekonomik düzey ile ebeveyn ve çocuğun değer benzerliği arasındaki ilişkinin ele alındığı bir çalışmaya ulaşılamamıştır. Ebeveynin eğitim düzeyi ve aylık geliri gibi faktörlerin, ebeveyn ve çocuğun değer benzerliğiyle ilişkisinin incelenmesi sosyoekonomik düzeyin rolünün daha iyi anlaşılabilmesi açısından önem taşımaktadır.

Yukarıda da bahsedildiği gibi, orta çocukluğun bilişsel ve sosyo-duygusal becerilerin edinildiği kritik bir dönem olması ve ebeveynler dışındaki diğer yetişkinler ve akranlar gibi diğer sosyalleştirme aktörleri ile ilişki kurulması bu dönemdeki değer gelişiminin çalışılmasını önemli hale getirmektedir. Her ne kadar akranlar, öğretmenler ve diğer yetişkinlerle kurulan etkileşim artmış olsa da, ebeveynler orta çocukluk döneminde en önemli sosyalleştirme aktörleri olmaya devam etmektedir. Özellikle, babalara kıyasla birincil bakım verenler olarak annelerin çocuklarıyla daha fazla zaman geçirmesi değer aktarımının gerçekleşmesi konusunda onlara firsat sunmaktadır (Kuczynski ve Grusec, 1997). Değer aktarımı sürecinde annelerin etkili şekilde rol alması sebebiyle bu çalışmada anne-çocuk değer benzerliği ele alınmıştır. Ancak orta çocukluk döneminde hem değer öncelikleri hem de anne-çocuk değer benzerliğini inceleyen çalışmaların oldukça kısıtlı olduğu dikkat çekmektedir (Döring ve ark., 2017). Bu bilgilerden hareketle, bu çalışmanın temel amacı orta çocukluk döneminde anneler ve çocuklarının değerlerine ilişkin örüntüyü ortaya koymaktır. Bu amaçla ilk olarak anne-çocuk çiftlerinin Schwartz'ın 10 değer tipi ve dört üst değer boyutu açısından ne derece benzerlik gösterdiği değerlendirilecektir. Yetişkinlik döneminde değerlerin ölçülmesi için kullanılan ölçeklerin yüksek dil becerisi, bilişsel beceri ve soyut düşünme yeteneği gerektirmesi sebebiyle, çocukluk döneminde değerlerin ölçülmesi için geliştirilen RDDT (Döring ve ark., 2010) çocukların dikkatini toplamada daha verimli çalışan ve soyut materyalleri resimler üzerinden somutlaştıran bir ölçüm aracıdır. Bahsedilen ölçüm aracı kullanılarak gözlem ya da ebeveyn bildirimi gibi dolaylı yollar yerine doğrudan öz bildirim yoluyla çocukların değerlerini değerlendirilecektir. Çalışmanın ikinci amacı ise anne-çocuk çiftlerinin değer benzerliği ile annenin eğitim düzeyi, toplam aylık gelir, çocuğun yaş1 ve cinsiyeti arasındaki ilişkilerin incelenmesidir. Anne-çocuk değer benzerliğinin ilgili değişkenlere göre farklılaşması beklenmektedir. Bu doğrultuda çalışmanın hipotezleri şu şekildedir: 
H1: Çocukların değerleri yetişkinlerde belirtilen değerlerle paralel bir yapı sergileyecektir.

H2: Annenin eğitim düzeyi arttıkça anne-çocuk değer benzerliği azalacaktır.

H3: Aylık gelir arttıkça anne-çocuk değer benzerliğinin azalacaktır.

H4: Annenin eğitim düzeyi ve aylık gelir ile anne-çocuk değer benzerliği arasındaki ilişkiler, kız ve erkek çocuklarda (cinsiyete göre) farklılaşacaktır.

H5: Annenin eğitim düzeyi ve aylık geliri ile anne-çocuk değer benzerliği arasındaki ilişkiler, küçük ve büyük yaştaki çocuklarda (çocuğun yaşına göre) farklılaşacaktır.

\section{YÖNTEM}

\section{Katılımcılar}

Çalışmaya Ankara' da yaşayan yaşları altı ile $11($ Ort. $=8.5, S S=1.23)$ arasında değişen ilkokul 1., 2., 3. ve 4. sınıfa devam eden 172 öğrenci ve anneleri katılmıştır. Öğrencilerin 81'i k1z (\%47.1), 90’1 erkektir (\%52.6) ve bir öğrencinin de cinsiyeti rapor edilmemiştir. Annelerin yaşları 28 ile 52 arasında (Ort. $=37.31$, SS = 4.75) değişmektedir. Annelerin \%5.4'ü ilkokul, \%4.2'si ortaokul, \% 32.7'si lise, \%12,5'i ön lisans, \%38.7'si üniversite, \%5.4'ü yüksek lisans ve \%1.2'si doktora düzeyinde eğitim aldığını rapor etmiştir. Annelerin \%56.8'inin çalıştığ1 ve mesleki dağılımı incelendiğinde öğretmen, muhasebeci ve devlet memurluğu gibi profesyonel mesleklere sahip oldukları görülmüştür. Annelerin \%5.2'si 0-1000 TL, \%44.8'i 1000-3000 TL, \%39'u 3000-5000 TL, \%8.4'ü 5000-7500 TL, \%1.9'u 7500-10000TL arasında ve \%.6's1 10000 TL ve üstü toplam aylık gelire sahip olduklarını belirtmişlerdir.

\section{Veri Toplama Araçları}

Portre Değerler Anketi (PDA). Schwartz ve arkadaşları (2001) tarafindan 11 yaş ve üzeri bireylerin değer yönelimlerini ölçmek amacıyla geliştirilmiş, 6'lı Likert tipi puanlanan 40 maddelik bir ölçektir. Ankette değerlendirilen değer tipleri güç, başarı, hazcılık, uyarılım, özyönelim, evrenselcilik, iyilikseverlik, geleneksellik, uyma ve güvenliktir. Ayrıca bu 10 değer tipini kapsayan yeniliğe açıklık (uyarılım, özyönelim), özaşkınlık (evrenselcilik, iyilikseverlik), muhafazacılık (geleneksellik, uyma, güvenlik), özgenişletim (güç, başarı) olmak üzere dört değer boyutu oluşturulmaktadır (Bkz. Şekil 1). Ölçeğin 40 maddelik formunun Türkçeye uyarlama çalışması, Demirutku ve Sümer 
(2010) tarafından gerçekleştirilmiştir. Elde edilen sonuçlar, PDA'nın değer yapılarının ve alt değer tiplerinin değerlendirilmesinde uygun, geçerli ve güvenilir bir ölçme aracı olduğunu ortaya koymuştur. Bu çalışmada, PDA'nın 21 maddelik kısa formu kullanılmıştır. PDA, Türkiye'nin de içinde yer aldığı Avrupa Sosyal Taramalar Araştırmasında (ESS) gözden geçirilerek 21 maddeye indirgenmiş, geçerli ve güvenilir bir ölçme arac1 olduğu ortaya konmuştur (European Social Survey-ESS, 2008). Çalışmada, 21 maddelik PDA'nın Çok Boyutlu Ölçekleme Analizi (Multi-dimensional Scaling: MDS) sonuçlarından elde edilen bulgular, ölçeğin .077'lik Stres I değerine sahip olduğunu ve Schwartz'ın önerdiği kuramsal modelle iyi uyum sağladığını göstermiştir.

Çocuklar için Resme Dayalı Değerler Taraması (RDDT). Ölçek Schwartz'ın tanımladığı değer tiplerinden yola çıkarak tasarlanmış resimler aracılığıyla altı ile 11 yaş arasındaki çocukların değer yönelimlerini ölçmek amacıyla geliştirilmiştir (Döring, 2010; Döring ve ark., 2010). Çocuklar için RDDT, Schwartz'ın tanımladığı 10 değer tipinin her biri için iki resim ve her resmin altında o değer tipi ile ilgili tanım olacak şekilde tasarlanmıştır. Bu 10 değer tipi güç (zengin ve güçlü olmak, lider olmak), başarı (en iyi olmak, başarılı olduğunu göstermek), hazcılık (hayatın tadını çıkarmak, keyfine bakmak), uyarılım (heyecanlı şeyler yapmak, maceraya atılmak), özyönelim (yeni şeyler keşfetmek ve merak etmek, yaratıcı olmak), güvenlik (tehlikelerden korunmak, güvenli bir yere sahip olmak), uyma (kurallara uymak, diğerleri gibi olmak), geleneksellik (dua etmek, geleneklere saygılı olmak), iyilikseverlik (başkalarına yardım etmek, başkalarını sevindirmek) ve evrenselcilik (yabancılar ile dostluk kurmak, doğayı korumak) şeklindedir (Bkz. Şekil 1). Ölçeğin Türkçeye uyarlama çalışması ilk olarak Almanya'da yaşayan Türk çocuklar için Şimşek tarafından (akt. Petersen, 2013), sonrasında Türkiye'de yaşayan çocuklar için Petersen (2013) tarafından yapılmıştır. Çok Boyutlu Ölçekleme Analizi (MDS) sonuçlarından elde edilen bulgular, ölçeğin .175'lik Stres I değerine sahip olduğunu ve Schwartz'ın önerdiği modelle iyi uyum sağladığını ortaya koymuştur (Petersen, 2013). Tarihsel olarak yakın zamanlı bir çalışmada, çok boyutlu ölçekleme analizi kapsamında elde edilen değer diziliminin, Schwartz'nn öne sürdüğü değer dizilimine çok benzer bir dağılım gösterdiği ve öngörülen kuramsal modelin doğrulandığ görülmüştür (Çakmak ve ark., 2018).

\section{İşlem}

Araştırmanın yürütülmesi için Ankara İl Milli Eğitim Müdürlüğünden ve üniversitenin Etik Komisyonundan gerekli izinler alınmıştır (08.04.2015-3705). Araştırma verile- 
ri 2014-2015 eğitim öğretim dönemi bahar yarıyılında Ankara’nın iki farklı ilçesinde bulunan üç ilkokuldan toplanmıştır. Okulların yöneticileri ile iletişime geçilerek çalışma hakkında bilgi verildikten sonra yöneticilerin izniyle ve rehber öğretmenler aracılığıyla, toplam 218 ilkokul (1., 2., 3. ve 4. sınıf) öğrencisi ve annelerine ulaşılmıştır. Annelere çocukları aracılığıyla bilgilendirilmiş onam formu ve anket formları gönderilmiştir. Sonrasında annelerinin onay vermiş olduğu çocuklara sözel bilgilendirilme yapılmış ve 10-15 kişilik gruplar halinde resme dayalı değerler taraması uygulanmıştır. Bunun için öncelikle 10 değeri ifade eden 20 resimden her biri projeksiyonla yansitılarak çocuklara tek tek gösterilmiş ve çocuklardan resimdeki ana karakterin neler yaptığını dikkatle incelemeleri istenmiştir. Daha sonra resimli etiketlerin olduğu formlar çocuklara dağıtılarak onlardan yönergeler doğrultusunda resimleri kendileri için öncelikli olanlardan başlamak üzere şablona yerleştirmeleri istenmiştir. Çocuklarla sınıf ortamında uygulama yaklaşık 20-25 dakikada tamamlanmıştır.

\section{Veri Analizi}

Verilerin analizinde IBM SPSS 22 programı kullanılmıştır. Çalışmada temel analizlere geçilmeden önce veri temizleme işlemi yapılmıştır. Analizlerin anne-çocuk çiftleri ile yürütülmesi planlandığından PDA'yı doldurmayan ya da eksik bırakan 20 anne, çocuklar için RDDT uygulamasına katılmamış olan 26 çocuk çalışma dışı bırakılarak 172 anne-çocuk çifti ile analizlere devam edilmiştir.

Çalışmanın temel amacı çerçevesinde istatistiksel analizler üç bölümde uygulanmıştır. İlk bölümde, anne ve çocuğun araştırma kapsamında ele alınan 10 değer ve dört üst değer boyutuna ait betimleyici istatistiklerine yer verilmiştir. Anne ve çocukların 10 değer tipi ve 4 üst değer boyutuna dair elde edilen ortalamalar önceki çalışmalarda yapıldığı gibi kendi içinde sıralamaya dönüştürülmüştür (Bkz. Tablo 2) (Demirutku, 2007; Karakitapoğlu-Aygün ve İmamoğlu, 2002). İlgili diğer çalışmalarda olduğu gibi bu sıralama anne ve çocukların değer önceliklerinin belirlenmesi için referans alınmıştır (Demirutku, 2007; Döring ve ark., 2010; Petersen, 2013). İkinci bölümde, anne ve çocuğun 10 değer tipi açısından ne derece benzerlik gösterdiği bağımlı örneklemler $t$-testi analizi ve Pearson Momentler Çarpımı korelasyon katsayısı hesaplanarak incelenmiştir. Üçüncü bölümde ise, anne-çocuk çiftlerinin değer benzerliği ile annenin eğitim düzeyi, toplam aylık gelir, çocuğun yaşı ve cinsiyeti arasındaki ilişkilerin incelenmesi amacıyla Pearson momentler çarpımı korelasyon analizi kullanılmıştır. 


\section{BULGULAR}

\section{Betimleyici Analizler}

Altı ile 11 yaşları arasındaki çocuklar ve annelerinin değer önceliklerini belirlemek için 10 değer ve dört değer boyutuna ait ortalama ve standart sapma değerleri hesaplanmış ve Tablo 2'de sunulmuştur. PDA'da evrenselcilik değerini temsil eden üç madde, diğer değerleri temsil eden iki madde olması sebebiyle elde edilen ortalamalar madde sayısına bölünerek hesaplanmıştır. Annelerin değer ortalamalarına benzer şekilde, çocukların 10 değer tipine ilişkin puanları da aritmetik ortalama alınarak elde edilmiştir. Hem anneler hem de çocuklar için değer boyutlarının ortalamaları oluşturulurken özgenişletim, özaşkınlık ve yeniliğe açıklık boyutlarının ikişer ve muhafazacılık boyutunun üç değer içermesi sebebiyle, elde edilen ortalamalar değer sayısına bölünerek hesaplanmiştır.

Tablo 2. Anneler ve Çocukların Değerlerine İlişkin Ortalama, Standart Sapma ve Değerlerin Karşılaştırılması

\begin{tabular}{|c|c|c|c|c|c|c|}
\hline \multirow[b]{2}{*}{ Değer Tipi } & \multicolumn{2}{|c|}{ Anne } & \multicolumn{2}{|c|}{ Çocuk } & \multirow[b]{2}{*}{$t$} & \multirow[b]{2}{*}{$p$} \\
\hline & Ort. & $S S$ & Ort. & $S S$ & & \\
\hline Güç & $3.67(8)$ & 1.06 & $2.56(9)$ & 0.93 & 2.85 & .005 \\
\hline Başarı & $3.92(1)$ & 1.40 & $3.11(5)$ & 0.74 & .86 & .392 \\
\hline Hazcılık & $3.70(7)$ & 1.61 & $2.48(10)$ & 0.87 & 4.74 & .000 \\
\hline Uyarılım & $3.63(10)$ & 1.35 & $2.65(7)$ & 0.89 & 2.29 & .023 \\
\hline Özyönelim & $3.79(3)$ & 1.59 & $2.76(6)$ & 0.67 & 3.54 & .001 \\
\hline Evrenselcilik & $3.70(6)$ & 1.88 & $3.27(3)$ & 0.64 & -3.27 & .001 \\
\hline İyilikseverlik & $3.74(5)$ & 1.82 & $3.57(2)$ & 0.52 & -7.73 & .000 \\
\hline Geleneksellik & $3.65(9)$ & 1.69 & $3.73(1)$ & 0.63 & -9.64 & .000 \\
\hline Uyma & $3.74(4)$ & 1.55 & $2.63(8)$ & 0.54 & 4.69 & .000 \\
\hline Güvenlik & $3.80(2)$ & 1.79 & $3.24(4)$ & 0.68 & -2.10 & .037 \\
\hline \multicolumn{7}{|l|}{4 Değer Boyutu } \\
\hline Yeniliğe açıklık & 3.71 & 1.29 & 2.70 & 0.54 & 4.14 & .000 \\
\hline Özaşkınlık & 3.72 & 1.82 & 3.42 & 0.43 & -6.09 & .000 \\
\hline Muhafazacılık & 3.73 & 1.54 & 3.20 & 0.37 & -4.02 & .000 \\
\hline Özgenişletim & 3.80 & 1.06 & 2.83 & 0.66 & 2.41 & .017 \\
\hline Değer Benzerliği & Ort. & $S S$ & \multicolumn{2}{|c|}{ Olası Ranj } & \multicolumn{2}{|c|}{ Gözlenen Ranj } \\
\hline Anne-çocuk & -.03 & .41 & \multicolumn{2}{|c|}{$-1.00-1.00$} & \multicolumn{2}{|c|}{$-.88-.86$} \\
\hline
\end{tabular}

Not. Anne ve çocukların değer tiplerine ait öncelik sıralaması parantez içinde verilmiştir.

Tablo 2'ye göre, anneler için başarı, güvenlik ve özyönelim değerleri ile özgenişletim ve muhafazacılık üst değerlerinin önemli olduğunu göstermiştir. Çocuklar ise geleneksellik, iyilikseverlik ve evrenselcilik değerleri ile özaşkınlık ve muhafazacılık üst değerlerinin kendileri için öncelikli değerler olduğunu belirtmişlerdir. 


\section{Anne-Çocuk Çiftlerinin Değerlerinin Karşılaştırılması}

İlgili analizlerden önce, anneler için PDA'nın 21 maddesinden elde edilen ortalama, 10 değer tipi puanlarından çıkarılarak merkezileştirilmiştir. Benzer şekilde, çocukların Çocuklar için RDDT'ye ait 20 resimden elde ettikleri ortalama 10 değer tipi puanından çıkarılarak merkezileştirilmiştir. Böylelikle, değerlendirme araçlarının kullanılmasında bireysel farklılıklardan kaynaklanan yanlılığın kontrol edilmesi ve puanların standardize hale getirilmesi sağlanmaktadır (Demirutku ve Sümer, 2010; Kuşdil ve Kağıtçıbaş1, 2000; Schwartz, 1992).

Anneler ve çocuklarının 10 değer tipinin karşılaştırılması amacıyla değer tipleri için 10 ayrı $t$-testi yapıldığından artan Birinci Tip Hata olasılığının kontrol edilmesi amacıyla anlamlılık düzeyi .05/10 = .005 olarak belirlenmiştir. Benzer şekilde anne ve çocuklarının dört üst değer boyutunun karşılaştırılması amacıyla dört ayrı $t$-testi yapıldığ 1 için anlamlılık düzeyi $.05 / 4=.0125$ olarak belirlenmiştir. $t$-testi sonucuna göre istatistiksel olarak anlamlı olan farkların etki büyüklüklerinin belirlenmesi amacıyla Cohen'in (1988) $d$ istatistiği hesaplanmıştır.

Tablo 2'ye göre, annelerin güç değer ortalaması (Ort. $=3.67, S S=1.06)$ çocuklarının güç değer ortalamasından $($ Ort. $=2.56, S S=.93)$ anlamlı olarak daha yüksektir $\left(t_{171}=\right.$ 2.85, $p=.005, d=.22$ ). Benzer şekilde, annelerin hazcılık değer ortalamasının (Ort. $=$ $3.70, S S=1.61)$ çocuklarının hazcılık değer ortalamasından $\left(\right.$ Ort. $=2.48, S S=.87, t_{171}=$ $4.74, p<.001, d=.36)$ ve özyönelim değer ortalamasının da $($ Ort. $=3.79, S S=1.59)$ çocuklarının özyönelim değer ortalamasından (Ort. $=2.76, S S=.67)$ anlamlı olarak daha yüksek olduğu görülmüştür $\left(t_{171}=3.54, p<.005, d=.28\right)$. Annelerin evrenselcilik değer ortalaması (Ort. $=3.70, S S=1.88)$ çocuklarının evrenselcilik değer ortalamasından $\left(\right.$ Ort. $\left.=3.27, S S=.64, t_{171}=-3.27, p<.005, d=.25\right)$, iyilikseverlik değer ortalamas1 da $($ Ort. $=3.74, S S=1.82)$ çocuklarının iyilikseverlik değer ortalamasından (Ort. $=$ $3.57, S S=.52)$ anlamlı olarak daha yüksektir $\left(t_{171}=-7.73, p<.001, d=.56\right)$. Buna ek olarak, annelerin uyma değerine ait ortalamaları (Ort. $=3.74, S S=1.55)$ çocuklarının uyma değerine ait ortalamalarından $($ Ort. $=2.63, S S=.54)$ anlamlı olarak daha yüksek$\operatorname{tir}\left(t_{171}=4.69, p<.001, d=.36\right)$. Buna karşın, çocukların geleneksellik değerine ait ortalamalarının $($ Ort. $=3.73, S S=.63)$ annelerinin geleneksellik değerine ait ortalamalarından $\left(\right.$ Ort. $\left.=3.65, S S=1.69, t_{171}=-9.64, p<.001, d=.73\right)$ anlamlı olarak daha yüksek olduğu görülmüştür. Ancak annelerin başarı, uyarılım ve güvenlik değer ortalamaları ile çocukların başarı, uyarılım ve güvenlik değer ortalamaları arasında anlamlı farklılık bulunmamıştır. 
Annelerin yeniliğe açıklık üst değerine ait ortalamalarının (Ort. $=3.71, S S=1.29)$ çocuklarının yeniliğe açıklık değerine ait ortalamalarından (Ort. $=2.70, S S=.54)$ anlamlı olarak daha yüksek olduğu görülmüștür $\left(t_{171}=-4.14, p<.001, d=.32\right)$. Benzer şekilde, annelerin özaşkınlık üst değer ortalamasının (Ort. $=3.72, S S=1.82)$ çocuklarının özaşkınlık değer ortalamasından (Ort. $\left.=3.42, S S=.43, t_{171}=-.09, p<.001, d=.46\right)$ ve muhafazacıllk üst değer ortalamasının (Ort. $=3.73, S S=1.82)$ da çocuklarının muhafazacılık değer ortalamasından (Ort. $=3.42, S S=.37)$ anlamlı olarak daha yüksek olduğu görülmüştür $\left(t_{171}=-4.02, p<.005, d=.31\right)$. Ancak annelerin özgenişletim üst değerine ait ortalamaları ile çocukların özgenişletim değer ortalamaları arasında anlamlı farklılık bulunmamıştır.

Anne-çocuk çiftlerinin değer benzerliğinin incelenmesi amacıyla, her bir çift için anne ve çocuklarının 10 değer puanı arasındaki Pearson Momentler Çarpımı Korelasyon katsayıları hesaplanmıştır. Elde edilen katsayılar anne-çocuk değer benzerliği göstergeleri olarak kullanılmıştır. Benzerlik katsayılarının -1.00 ile +1.00 arasında değişmesi beklenmektedir ve +1.00 çiftler arasındaki mükemmel uyumu gösterirken -1.00 ise yüksek düzeyde değer uyumsuzluğunu ifade etmektedir. Elde edilen sonuçlara göre, anne-çocuk çiftleri arasındaki değer benzerliğinin normal dağılım gösterdiği ancak ortalama olarak çiftler için değer benzerliğinin negatif uca yakın olduğu görülmüştür $($ Ort. $=-.03, S S=.41$, ranj $=-.88-.86)$. Dolayısıyla anne-çocuk çiftleri değer öncelikleri açısından düşük benzerlik göstermektedir.

Anne-çocuk çiftlerinin 10 değer tipine ait öncelik sıralamasının ne derece benzer ya da farklı olduğunun belirlenmesi amacıyla Spearman Sıra Farkları Korelasyon katsayısı hesaplanmıştır. Analiz sonucuna göre anne ve çocukların değer sıralamaları arasında anlamlı bir ilişki olmadığı anne ve çocukların 10 değer tipi önceliklerini ifade eden değer sıralamalarının benzer olmadığı görülmüştür $\left(N=10, r_{\mathrm{s}}=.12, p>.05\right)$.

\section{Anne-Çocuk Çiftlerinin Değer Benzerliği ile İlişkili Faktörler}

Anne-çocuk çiftlerinin değer benzerliği ile annenin eğitim düzeyi, toplam aylık gelir, çocuğun yaşı ve cinsiyeti arasındaki ilişkilerin incelenmesi amacıyla Pearson Momentler Çarpımı korelasyon analizi yapılmıştır. Analiz sonucunda annenin eğitim düzeyi $(r(2,170)=-.19, p<.05)$ ve toplam aylık gelirin $(r(2,170)=-.17, p<.05)$ anne-çocuk çiftlerinin değer benzerliğiyle negatif yönde ilişkili olduğu, ancak çocuğun yaşı $(r(2$, $170)=.01, p=.92)$ ve cinsiyetinin $(r(2,170)=.02, p=.77)$ ilişkili olmadığ görülmüştür. 
Annelerin eğitim düzeyi ve toplam aylık gelirin, değer benzerliği ile olan ilişkisinin çocuğun yaşına ve cinsiyetine göre nasıl bir örüntü sergilediğini incelemek amaciyla Pearson Momentler Çarpımı korelasyon analizi yapılmıştır. Öncelikle, çocukların yaşı sınıf düzeyi esas alınarak küçük yaş (1. ve 2. sınıf) ve büyük yaş (3. ve 4. sınıflar) olmak üzere iki grup haline getirilmiştir. Elde edilen bulgulara göre, eğitim düzeyi ve toplam aylık gelir ile anne-çocuk çiftlerinin değer benzerliği arasındaki ilişkilerin çocuğun yaŞına göre farklılaştığı görülmüştür. Annenin eğitim düzeyi $(r(2,170)=-.09, p=.39)$ ve toplam aylık gelir $(r(2,170)=.03, p=.81)$ küçük yaş grubundaki anne-çocuk çiftlerinin değer benzerliği ile ilişkili değilken, büyük yaş grubundaki anne-çocuk çiftlerinin değer benzerliği ile annenin eğitim düzeyi $(r(2,170)=-.26, p<.05)$ ve toplam aylık gelir $(r(2$, $170)=-.41, p<.001)$ negatif yönde ilişkilidir. Bir başka deyişle, annelerinin eğitim düzeyi ve ailenin toplam aylık geliri arttıkça annelerin değerleri ile büyük yaştaki çocukların değerleri arasındaki benzerlik azalmaktadır. Buna ek olarak, eğitim düzeyi ve toplam aylık gelir ile anne-çocuk çiftlerinin değer benzerliği arasındaki ilişkinin çocuğun cinsiyetine göre de farklılaştığ1 görülmüştür. Annenin eğitim düzeyi $(r(2,170)=-.25, p<$ $.05)$ ve toplam aylık gelirin $(r(2,170)=-.27, p<.05)$ anne-kız çocuk çiftlerinin değer benzerliği ile negatif yönde ilişkili olduğu, ancak anne-erkek çocuk çiftlerinin değer benzerliği ile annenin eğitim düzeyi $(r(2,170)=-.13, \mathrm{p}=.24)$ ve toplam aylik gelirin $(r(2,170)=-.07, \mathrm{p}=.57)$ ilişkili olmadığı görülmüştür. Dolayısıyla, annelerin eğitim düzeyi ve ailenin toplam aylık geliri arttıkça, annenin değerleri ile kız çocuklarının değerleri arasındaki benzerliğin azaldığı, bir diğer deyişle, annenin eğitim düzeyi ve ailenin toplam aylık geliri azaldıkça, anne ve kız çocukları arasındaki değer benzerliğinin arttığ1 görülmektedir.

\section{TARTIŞMA}

Bu çalışmada anne-çocuk çiftlerinin Schwartz'ın (1992) 10 değer tipi ve dört üst değer boyutu açısından ne derece benzerlik gösterdiği incelenmiştir. Anneler, değer sıralamalarında başarı, güvenlik ve özyönelim değerleri ile özgenişletim ve muhafazacılık üst değerlerinin ilk sıralarda yer aldığını belirtirken, çocuklar geleneksellik, iyilikseverlik ve evrenselcilik değerleri ile özaşkınlık ve muhafazacılık üst değerlerinin değer sıralamalarında ilk sıralarda yer aldığını belirtmişlerdir. Buna ek olarak anneler güç, hazcılık, özyönelim, evrenselcilik, iyilikseverlik ve uyma değerlerinde çocuklara kıyasla daha yüksek puan alırlarken, çocuklar geleneksellik değerinde annelere kıyasla daha yüksek puan almışlardır. Ayrıca anne-çocuk çiftlerinin değerlerinin genel olarak düşük 
benzerlik gösterdiği ve değer tiplerine ait öncelik sıralamalarının birbirlerinden farkl1laştığı görülmüştür. Bunun yanı sıra, çalışmada anne-çocuk çiftlerinin değer benzerliğinde annenin eğitim düzeyi ve toplam aylık gelirin etkili olduğu ve bu etkinin çocuğun yaşı ve cinsiyetine göre farkl1lık gösterdiği ortaya konmuştur.

Bulgular genel olarak anne-çocuk çiftlerinin değerlerinin farklılaştı̆̆ını göstermiştir. Anneler açısından bakıldığında, başarı, güvenlik ve özyönelim değerleri ile özgenişletim ve muhafazacılık üst değerlerinin önemli olduğu görülmüştür. Mevcut çalışma, genç ve orta yetişkinlik dönemlerindeki bireylerin güç, başarı, uyarılım, özyönelim ve yeniliğe açıklık gibi kendi odaklı değerlere daha fazla önem verdiğini gösteren alan yazındaki diğer çalışmalarla benzer bulgular ortaya koymuştur (örn., Tulviste ve ark., 2017; van Herk ve Poortinga 2012). Genç yetişkinlik döneminde birey evlilik ve aile, sosyal ilişkiler, iş yaşamı ve kariyer düzenlemesi gibi pek çok farklı alanla ilgili gelişimsel görevin üstesinden gelmeye çalışmakta ve bu alanlardaki başarıya odaklanmaktadır. Orta yetişkinlik döneminde ise birey sosyal ilişkiler ve kariyerinde elde ettiği güç ve başarıya odaklanarak mevcut durumunu korumayı amaçlamaktadır. Buradan hareketle, değerlerin motivasyonel temelleri de göz önünde bulundurulduğunda, genç ve orta yetişkinlik dönemlerindeki bireylerin kendi odaklı değerlere önem vermesinin gelişimsel hedefleriyle tutarlılık gösterdiği söylenebilmektedir. Çocukların değerler sıralamasına bakıldığında ise geleneksellik, iyilikseverlik ve evrenselcilik değerleri ile özaşkınlık ve muhafazacllık üst değerlerinin çocuklar için öncelikli değerler olduğu görülmüştür. Orta çocukluk döneminde gelişen sosyo-bilişsel yetenekler (örn., perspektif alma, diğerinin niyetini anlayabilme) sonucunda diğeri odaklı anlayış gelişmekte ve diğeri yönelimli değerleri anlayıp içselleştirmede artış görülmektedir. Dolayısıyla bu dönemdeki çocukların yaşamlarında diğeri odaklı değerler daha fazla önem kazanmaktadır. Çalışmadan elde edilen bulguların, alan yazındaki kısıtlı sayıdaki araştırma bulgusunu destekler nitelikte olduğu ve ilgili gelişim döneminin beklendik bir çıktısı olarak değerlendirilebileceği görülmektedir (örn., Daniel ve ark., 2020; Döring ve ark., 2010; Petersen, 2013).

Annelerin güç, hazclllk, özyönelim, evrenselcilik, iyilikseverlik ve uyma değerlerine ait ortalamaları çocuklarına kıyasla daha yüksektir. Değer yapılarının yetişkinlik döneminde çocukluk dönemine kıyasla daha ayrışmış bir örüntü sergilemesi, annelerin birçok değer ortalamasının daha yüksek olmasını açıklayabilir (örn., Bubeck ve Bilsky, 2004). Buna ek olarak, çocukların geleneksellik değerine ait ortalamaları annelere k1yasla daha yüksektir. Benzer şekilde Döring, Kärtner ve Bilsky (2018) uyma, gelenek- 
sellik ve güvenlik değerlerini kapsayan muhafazacılık üst değerine çocukların ebeveynlerinden daha fazla önem verdiğini göstermiştir. Orta çocukluk döneminde çocuklar birçok alanda başarı elde etmek için çabalamaktadır ve diğerlerinin performanslarını değerlendirdiğinin farkına varmaktadırlar. Ancak, çocukların bu çabaları başarı ya da başarısızlıkla sonuçlanabilir. Dolayısıyla, bu dönemde yetkinlik ve alçakgönüllülük arasındaki dengenin önemli olduğu öne sürülmektedir. Uyum, alçakgönüllülük, sosyal ve aile ilişkilerindeki normlar ise geleneksellik değerinin önemli bileşenleridir. Bu bilgiler doğrultusunda değerlendirildiğinde, orta çocukluk döneminin psikososyal gelişim özellikleri çocukların geleneksellik değerine daha fazla önem vermesini açıklayabilmektedir.

Çalışmadan elde edilen bulgulara göre, anne-çocuk çiftleri 10 değer tipi açısından düşük benzerlik göstermekte ve değer tiplerine ait öncelik sıralamaları birbirlerinden farklılaşmaktadır. Yukarıda ele alınan araştırma bulguları ile birlikte değerlendirildiğinde, anne-çocuk çiftlerinin 10 değer tipi açısından düşük benzerlik göstermesi beklendik yönde bir bulgudur. Çalışmada anneler kendi odaklı başarı ve özyönelim değerleri ile diğeri odaklı güvenlik değerinin, çocuklar ise diğeri odaklı değerler olan geleneksellik, iyilikseverlik ve evrenselcilik değerlerinin kendileri için en önemli değer olduğunu belirtmişlerdir. Gelişimsel olarak, çocukluk dönemi boyunca diğeri yönelimli anlayışın gelişmesi ile birlikte diğeri odaklı değerlerin önemi artmaktadır. Ergenlik döneminde ise kimlik kazanımı ve özerk ahlaka geçiş ile birlikte ergenler kişisel hedef ve amaçları doğrultusunda yetişkinlere benzer şekilde kendi odaklı değerlere daha fazla önem vermeye başlamaktadır. Dolayısıyla çalışmadaki annelerin ve çocukların içinde bulundukları gelişimsel dönemin özelliklerini yansıtan değer önceliklerine sahip olduklarını söylemek mümkündür. Elde edilen bu yöndeki sonuçlar, ergenlere kıyasla ebeveynler ve daha küçük yaştaki çocukların değer önceliklerinin benzerlikten çok farklılık gösterdiğini ortaya koyan araştırma bulgularını destekler niteliktedir (Barni ve ark, 2011; Demirutku, 2007; Koç, 2013; Tosun, 2015).

Çalışmada ayrıca anne-çocuk çiftlerinin değer benzerliği ile annenin eğitim düzeyi ve aylık gelir arasındaki ilişkinin anlamlı olduğu ve bu ilişkinin çocuğun yaşı ve cinsiyetine göre farklılaştığı görülmüştür. Bu sonuca göre, annenin eğitim düzeyi ve toplam aylık gelir küçük yaştaki çocuklar ve annelerinin değer benzerliği ile ilişkili bulunmamıştır. Buna karşılık, annenin eğitim düzeyi ve toplam aylık gelir büyük yaştaki çocuklar ve annelerinin değer benzerliği ile negatif yönde ilişkilidir. Bu bulgu, annelerin 
eğitim düzeyi ve toplam aylık gelir arttıkça büyük yaştaki çocuklar ile annelerinin değer benzerliğinin azaldığına işaret etmektedir. Sonuçlar, annelerin sosyoekonomik düzeyinin özellikle büyük yaştaki çocukların değer kazanımında önemli bir role sahip olduğunu göstermektedir. Yüksek sosyoekonomik düzeye sahip anneler özyönelim ve yeniliğe açıklık gibi kendi odaklı değerlere daha çok önem vermekte ve kendi değerlerini zorla kabul ettirmek yerine çocukların içinde bulunduğu gelişim döneminin özelliklerini göz önünde bulundurarak o döneme özgü değerlerin içselleştirilmesini desteklemektedirler (Bilsky ve ark., 2013; Tulviste, 2013; Uzefovsky ve ark., 2016). Buna karşın, düşük sosyoekonomik düzeyden gelen anneler, uyma ve geleneksellik gibi diğer odaklı değerlere daha fazla önem vermektedirler. Düşük sosyoekonomik düzeyden gelen annelerin, küçük yaştaki çocuklara kıyasla, büyük yaştaki çocuklarına değerler kazanımı konusunda daha otoriter ve baskıcı davranarak çocuğun özerk bir şekilde kendi değerlerini içselleştirmesine firsat tanımama ve kendi kişisel değerlerini dayatma eğiliminde oldukları görülmektedir (Tulviste, 2013; Uzefovsky ve ark., 2016).

Çalışmada annenin eğitim düzeyi ve toplam aylık gelir ile anne-çocuk değer benzerliği arasındaki ilişkiyi ortaya koyan bulgular, kız ve erkek çocuklar için farklılık göstermiştir. Annenin eğitim düzeyi ve toplam aylık geliri anne ve kız çocuklarının değer benzerliği ile negatif yönde ilişkiliyken, anne ve erkek çocuklarının değer benzerliği ile ilişkili bulunmamıştır. Bu bulgu, annelerin eğitim düzeyi ve toplam aylık geliri azaldıkça anne ve kız çocuklarının değer benzerliğinin arttığına işaret etmektedir. Çalışmalar anne ve kız çocuklarının değerlerinin anne ve erkek çocuklarının değerlerine kıyasla daha fazla benzer olduğunu ve bu benzerliğin toplumsal cinsiyet rolleri temelinde açıklanabileceğini göstermiştir (Laghi, Pallini ve De Sclavis, 2012; Leaper ve Friedman, 2007). Eğitim düzeyi yüksek annelere kıyasla eğitim düzeyi düşük anneler, kurallara boyun eğme, sözünü tutma, tutumlu olma gibi sosyal normları vurgulayan diğeri odaklı değerlere daha fazla önem vermektedirler (Tulviste, 2013). Bununla birlikte, toplumsal cinsiyet rolleri temelinde bir sosyalleştirme sürecini daha fazla benimseyerek kız çocuklarının sosyalleşme sürecine daha fazla ilgi gösterebileceği ve bunun sonucunda kız çocuklarının kendi değerlerine uyum göstermesini ve itaat etmesini beklediği söylenebilir. Buna karşın, yüksek sosyoekonomik düzeyden gelen annelerin özyönelim ve yeniliğe açıklık gibi bağımsızlığı ve yeniliği vurgulayan kendi odaklı değerlere önem verdikleri söylenebilir. Eğitim düzeyi yüksek ve geliri daha iyi olan anneler kız çocuklarına kendi değerlerini dayatmak yerine geleneksel rollerin dışına taşarak onların özerliğini destek- 
lemekte ve değerlerin içselleştirilmesi için gerekli firsatların tanındığı bir sosyalleştirme süreci benimsedikleri düşünülmektedir. Dolayısıyla çalışmada elde edilen bulgular genel olarak sosyalleştirme sürecinde anne ve kız çocuklarının ilişkilerinin erkek çocuklara kıyasla daha iç içe geçmiş olduğunu ve kız çocuklarının bu ilişkiden etkilenme konusunda daha hassas olduğunu ortaya koyan çalışmalar ile tutarlılık göstermektedir (örn., Acar-Bayraktar, Çakmak ve Sarıtaş-Atalar, 2019; Laghi ve ark., 2012). Sonuç olarak yeterli veri bulunmamakla birlikte annenin sosyoekonomik düzeyinin yüksek olmaS1 kız çocuklarının değer kazanımı sürecindeki özerkliğini destekleyici bir rol oynuyor olabileceği, diğer yandan annenin düşük sosyoekonomik düzeye sahip olmasının ise kendi değerlerini kız çocuklarına dayattıkları bir değer kazanımı sürecini ortaya çıkarabileceği düşünülmektedir. Ancak gelecek araştırmalarda anne kız çocuk ve erkek çocuk değer benzerliği konusunda daha ayrıntılı inceleme yapılması daha doğru çıkarımlar yapmayı sağlayacaktır.

Özetle, çalışmada Schwartz' ın 10 değer tipi açısından anne-çocuk çiftlerinin benzerliğinin düşük olduğu ve değer tiplerine ait öncelik sıralamalarının farklılaştığı ortaya konmuştur. Ancak elde edilen bulgular çalışmanın sınırlılıkları dahilinde değerlendirilmelidir. İlk olarak, çocukluk dönemi boyunca ve ergenliğe geçişte ortaya çıkan değer yapılarının belirlenmesi açısından ortaya çıkan gelişimsel değişikliklerin incelenmesi önemli olacaktır. Gelecek çalışmalarda, ahlaki gelişim süreci içerisinde değerler kazanımı, değer önceliklerinde birey içi değişimlerin gözlenebilmesi ve anne-çocuk çiftlerinin benzerliğinin gelişimsel süreçte nasıl bir örüntü ortaya koyduğunun belirlenebilmesi için boylamsal desen kullanılması önerilmektedir. İkinci olarak, orta çocukluk döneminde okul, çocuklar için önemli bir sosyal bağlamdır ve zamanlarının çoğunu onlar için önemli diğer sosyalleştirme ajanları olan öğretmenler ve akranları ile geçirmektedirler. Dolayısıyla, akranlar ve öğretmenlerin değerlerin sosyalleştirilmesindeki rolünün ele alınması değer kazanımına dair daha kapsamlı bilgiler sağlayacaktır. Buna ek olarak, çalışma anne ve çocuklar ile yürütülmüştür. Anne ve çocuk arasındaki ilişkinin yakınlığ 1 sebebiyle anne-çocuk arasındaki ilişkinin baba-çocuk arasındaki ilişkiden daha yordayıc1 olduğu düşünülmektedir (Kuczynski ve Parkin, 2007). Buna rağmen, değer benzerliği açısından annelerin yanı sıra baba-çocuk çiftlerinin çalışılması değerli bilgiler ortaya koyabileceğinden gelecek çalışmaların her iki ebeveynin de katılımıyla yürütülmesi alan yazına katkı sağlayacaktır. Son olarak, her ne kadar bu çalışmada sosyoekonomik düzeye göre değerlendirme yapılmış olsa da, örneklemi Ankara’nın farklı ilçelerinde 
yaşayan görece homojen bir grup oluşturmaktadır. Buna rağmen, çalışmada anne-çocuk değer benzerliğinde annenin eğitim düzeyi ve toplam aylık gelir düzeylerinde farklılaşmaya dair önemli ipuçları ortaya konulmuştur. Çalışmanın, farklı şehirlerden ve farklı sosyoekonomik düzeylerden gelen eğitim ve gelir düzeyi açısından daha temsil edici bir örneklem grubuyla tekrarlanmasının elde edilen bulguların genellenebilirliğini arttıracağ1 düşünülmektedir. Son olarak, Schwartz ve arkadaşları (2012), Schwartz'ın (1992) Değer Kuramı'ndan yola çıkarak Türkiye'nin de dahil olduğu 10 ülkenin katılımıyla yürüttükleri çalışmalarında 10 değeri genişleterek 19 değer önermişler ve PDA'nın yeniden düzenlendiği 57 maddelik PDA57 ölçeğini geliştirmişlerdir. Ancak, mevcut araştırmada anne ve çocukların değer benzerliğinin incelenmesi amaçlandığından çocuklar için kullanılan RDDT ile örtüşmesi için 21 maddelik PDA kullanmıştır. Gelecek çalışmalarda bireylerin sahip oldukları değerlerin altında yatan motivasyonları daha ayrıntılı inceleyebilmek adına küçük çocuklar için kullanılan RDDT'nin, kuramın geliştirilmiş hali ile örtüşecek şekilde genişletilerek PDA57 ile birlikte kullanılması önerilmektedir. Değer benzerliğinin ele alındığı çalışmalarda yenilenen ölçüm araçlarının kullanımının, anne ve çocukların değerlerinin daha ayrıntılı değer boyutları aracılığıyla değerlendirilmesini sağlayacağından değer benzerliği konusunda kapsamlı bilgiler sunacağı öngörülmektedir.

Bahsedilen sınırlılıklara rağmen çalışma, Schwartz'ın değer kuramı temel alınarak Türkiye örnekleminde orta çocukluk dönemine odaklanan ve anne-çocuk çiftlerinin değer benzerliğinin incelendiği ilk çalışma olma niteliği taşımaktadır. Mevcut çalışmadan elde edilen sonuçlar, çocukların değer gelişimlerinin erken yaşlardan itibaren başladı̆̆ı$\mathrm{n} ı$ ve farklı gelişim dönemlerinde bazı değerlerin daha fazla önem kazandığını göstermiştir. Değerler eğitimi içeriği, ülkemizde Milli Eğitim Bakanlığı (Milli Eğitim Bakanlığı, 2018) tarafından okul öncesi, ilköğretim, ortaöğretim ve lise müfredatına eklenmiştir. Çalışmada ortaya konan farklı gelişim dönemlerinde farklı değerlerin öncelikli olması bilgisi, kademeler arasında değerler eğitiminin sadece niceliksel olarak değil, aynı zamanda içerik olarak da farklılaşması gerektiği konusunda yol göstericidir. Normal gelişim örüntüsü içinde değerlendirdiğimizde, kademe yükseldikçe (yaş arttıkça), eğitimin içeriğindeki vurgunun diğeri odaklı değerlerden kendi odaklı değerlere doğru bir değişimi içermesi önemli olabilir. Bunun yanı sıra, çalışmanın bulguları sosyoekonomik düzeyin anne-kız çocuğu değer benzerliğini farklılaştırdığını ortaya koymuştur. Buradan hareketle, özellikle düşük sosyoekonomik düzeye sahip çevrelerde, yaş dö- 
nemlerine uygun değerlerin neler olduğu, bu değerlerin sosyoduygusal gelişim açısından önemini vurgulayan ebeveyn eğitim programlarının düzenlenmesi önemli olabilir. Toplumdaki ahlaki değerler, gelenekler ve normların ebeveynler aracılığıyla gelecek kuşaklara aktarılması kültürün devamlılığının sağlanması açısından oldukça önemlidir. Mevcut çalışmada anne-çocuk değer benzerliğini ve bu benzerliği etkileyen faktörlere dair önemli ipuçları elde edilmiştir. Elde edilen bulgular göz önüne alındığında, kültürel değerler ve normların nesilden nesile aktarılmasında geleceği şekillendirecek olan çocukların nasıl bir role sahip olduğunun anlaşılması önemli olacaktır.

Hakem Değerlendirmesi: Dış bağımsız.

Yazar Katkıları: Çalışma Konsepti/Tasarım- Z.Ç., A.V.A.B., D.S.A., Z.U.; Veri Toplama- Z.Ç., A.V.A.B.; Veri Analizi/Yorumlama- Z.Ç., A.V.A.B., D.S.A., Z.U.; Yazı Taslağı- Z.Ç., A.V.A.B., D.S.A., Z.U.; İçeriğin Eleştirel İncelemesi- D.S.A., Z.U.; Son Onay ve Sorumluluk- Z.Ç., A.V.A.B., D.S.A., Z.U.

Çıkar Çatışması: Yazarlar çıkar çatışması bildirmemiştir.

Finansal Destek: Yazarlar bu çalışma için finansal destek almadığını beyan etmiştir.

Peer-review: Externally peer-reviewed.

Author Contributions: Conception/Design of Study- Z.Ç., A.V.A.B., D.S.A., Z.U.; Data Acquisition- Z.Ç., A.V.A.B.; Data Analysis/Interpretation- Z.Ç., A.V.A.B., D.S.A., Z.U.; Drafting Manuscript- Z.Ç., A.V.A.B., D.S.A., Z.U.; Critical Revision of Manuscript- D.S.A., Z.U.; Final Approval and Accountability- Z.Ç., A.V.A.B., D.S.A., Z.U.

Conflict of Interest: The authors have no conflict of interest to declare.

Grant Support: The authors declared that this study has received no financial support.

\section{Kaynakça/References}

Acar-Bayraktar, A. V., Cakmak, Z. ve Saritas-Atalar, D. (2019). Parenting and children's prosocial and problem behaviors in middle childhood: The role of Turkish mothers' emotion socialization practices. Social Development, 28(2), 333-346.

Akarslan Esen, M. ve Cesur, S. (2015). Üniversite öğrencilerinin ebeveynlik stillerini algılayışları ve bu algının ebeveyn-çocuk değer benzerliğine etkisi. Psikoloji Çalışmaları, 35(2), 1-24.

Barni, D., Alfieri, S., Marta, E. ve Rosnati, R. (2013). Overall and unique similarities between parents' values and adolescent or emerging adult children's values. Journal of Adolescence, 36(6), 11351141.

Barni, D., Ranieri, S. ve Scabini, E. (2012). Value similarity among grandparents, parents, and adolescent children: Unique or stereotypical? Family Science, 3(1), 46-54.

Barni, D., Ranieri, S., Scabini, E. ve Rosnati, R. (2011). Value transmission in the family: Do adolescents accept the values their parents want to transmit? Journal of Moral Education, 40(1), 105-121.

Bensalah, L., Stefaniak, N., Carre, A. ve Besche-Richard, C. (2016). The Basic Empathy Scale adapted to French middle childhood: Structure and development of empathy. Behavior Research Methods, 48(4), 1410-1420.

Bilsky, W., Döring, A. K., van Beeck, F., Rose, I., Schmitz, J., Aryus, K. ... ve Sindermann, J. (2013). Assessment of children's value structures and value preferences. Swiss Journal of Psychology, 72 , 123-136.

Bubeck, M. ve Bilsky, W. (2004). Value structure at an early age. Swiss Journal of Psychology, 63(1), $31-41$. 
Cashmore, J. A. ve Goodnow, J. J. (1986). Influences on Australian parents' values: Ethnicity versus socioeconomic status. Journal of Cross-Cultural Psychology, 17, 441-454.

Cieciuch, J., Davidov, E. ve Algesheimer, R. (2016). The stability and change of value structure and priorities in childhood: A longitudinal study. Social Development, 25(3), 503-527.

Cohen, J. (1988). Statistical power analysis for the behavioral sciences (2. bs.). Hillsdale, NJ: Lawrence Erlbaum Associates.

Çakmak, Z., Acar-Bayraktar, A. V. ve Sarıtaş-Atalar, D. (2018). Orta çocuklukta Resme Dayalı Değerler Taraması (PBVS) ile değerlerin ölçülmesi: Yaşa, cinsiyete ve anne eğitimine bağlı değişiklikler. Nesne Psikoloji Dergisi, 12, 1-26.

Daniel, E., Benish-Weisman, M., Sneddon, J. N. ve Lee, J. A. (2020). Value profiles during middle childhood: Developmental processes and social behavior. Child Development, 91(5), 1615-1630.

Demirutku, K. (2007). Parenting styles, internalization of values, and the self-concept. (Yayınlanmamış Doktora Tezi), Orta Doğu Teknik Üniversitesi, Ankara.

Demirutku, K. ve Sümer, N. (2010). Temel değerlerin ölçümü: Portre Değerler Anketi'nin Türkçe uyarlaması. Türk Psikoloji Yazllarl, 13(25), 17-25.

Döring, A. K. (2010). Assessing children's values: An exploratory study. Journal of Psychoeducational Assessment, 28(6), 564-577.

Döring, A. K., Blauensteiner, A., Aryus, K., Drögekamp, L. ve Bilsky, W. (2010). Assessing values at an early age: The picture-based value survey for children (PBVS-C). Journal of Personality Assessment, 92(5), 439-448.

Döring, A. K., Daniel, E. ve Knafo-Noam, A. (2016). Introduction to the special section value development from middle childhood to early adulthood - new insights from longitudinal and genetically informed research. Social Development, 25(3), 471-481.

Döring, A. K., Kärtner, J. ve Bilsky, W. (2018). Values in families with young children: Insights from two cultural milieus in Germany. International Journal of Psychology, 53(6), 486-495.

Döring, A. K., Makarova, E., Herzog, W. ve Bardi, A. (2017). Parent-child value similarity in families with young children: The predictive power of prosocial educational goals. British Journal of Psychology, 108(4), 737-756.

European Social Survey-ESS (2008). https://www.europeansocialsurvey.org/.

Gouveia, V. V., Vione, K. C., Milfont, T. L. ve Fischer, R. (2015). Patterns of value change during the life span: Some evidence from a functional approach to values. Personality and Social Psychology Bulletin, 41(9), 1276-1290.

Grusec, J. E. ve Davidov, M. (2007). Socialization in the family: The roles of parents. J. E. Grusec ve P. D. Hastings (Ed.), Handbook of socialization: Theory and research içinde (s. 614-637). New York, NY: Guilford Press.

Grusec, J. E. ve Goodnow, J. J. (1994). Impact of parental discipline methods on the child's internalization of values: A reconceptualization of current points of view. Developmental Psychology, 30(1), 4.

Hitlin, S. (2006). Parental influences on children's values and aspirations: Bridging two theories of social class and socialization. Sociological Perspectives, 49(1), 25-46.

Karakitapoğlu-Aygün, Z. ve İmamoğlu, E. O. (2002). Value domains of Turkish adults and university students. Journal of Social Psychology, 142, 333-351.

Knafo, A. ve Schwartz, S. H. (2009). Accounting for parent-child value congruence: Theoretical considerations and empirical evidence. Schönpflug (Ed.), Culture and psychology. Cultural transmission: Psychological, developmental, social, and methodological aspects içinde (s. 240268). Cambridge University Press.

Kochanska, G., Aksan, N., Prisco, T. R. ve Adams, E. E. (2008). Mother-child and father-child mutually responsive orientation in the first 2 years and children's outcomes at preschool age: Mechanisms of influence. Child Development, 79(1), 30-44. 
Koç, N. (2013). Annelerin kişisel değerleri ile beş-altı yaş çocuklarının değer kazanımları arasındaki ilişkiler. (Yayınlanmamış Doktora Tezi). Uludağ Üniversitesi, Bursa.

Kuczynski, L. ve Grusec, J. E. (1997). Future directions for a theory of parental socialization. J. E. Grusec ve L. Kuczynski (Ed.), Parenting and children's internalization of values: A handbook of contemporary theory içinde (s. 399-414). New York: Wiley.

Kuczynski, L., Marshall, S. ve Schell, K. (1997). Value socialization in a bidirectional context. J. E. Grusec ve L. Kuczynski (Ed.), Parenting and children's internalization of values: A handbook of contemporary theory içinde (s. 23-50). New York: Wiley.

Kuczynski, L. ve Parkin, C. M. (2007). Agency and bidirectionality in socialization: Interactions, transactions, and relational dialectics. J. E. Grusec ve P. D. Hastings (Ed.), Handbook of socialization: Theory and research içinde (s. 259-283). The Guilford Press.

Kuşdil, M. E. ve Kağıtçıbası, Ç. (2000). Türk öğretmenlerinin değer yönelimleri ve Schwartz değer kuram1. Türk Psikoloji Dergisi, 15(45), 59-76.

Laghi, F., Pallini, S. ve De Sclavis, R. (2012). Values similarity between parents and adolescents: A preliminary investigation among Italian adolescents. Journal of Comparative Family Studies, 43(6), 915-923.

Leaper, C. ve Friedman, C. K. (2007). The socialization of gender. J. E. Grusec ve P. D. Hastings (Ed.), Handbook of socialization: Theory and research içinde (s. 561-587). New York, NY: Guilford Press.

Milli Eğitim Bakanlığı (2018). Öğretim programlarl, 30.04.2020 tarihinde http://mufredat.meb.gov.tr/ Programlar.aspx adresinden alınmıştır.

Özvanligil, C. (2013). Multitrait-multimethod analysis of picture based values survey for children with portrait values questionnaire. (Yayınlanmamış Yüksek Lisans Tezi). İstanbul Bilgi Üniversitesi, İstanbul.

Petersen, A. (2013). Çocukların değerleri: Adaptation of the picture-based value survey for children $(P B V S-C)$ and validation in a Turkish sample. (Yayınlanmamış Yüksek Lisans Tezi). Vestfalya Wilhelm Üniversitesi, Münster.

Prince-Gibson, E. ve Schwartz, S. H. (1998). Value priorities and gender. Social Psychology Quarterly, 61, 49-67.

Santrock, J. W. (2012). Yaşam Boyu Gelişim (13. Baskı). (G. Yüksel, Çev.) Ankara: Nobel Yayıncılık. (Orijinal çalışma basım tarihi 2011).

Schwartz, S. H. (1992). Universals in the content and structure of values: Theoretical advances and empirical tests in 20 countries. Advances in Experimental Social Psychology, 25, 1-65.

Schwartz, S. H., Cieciuch, J., Vecchione, M., Davidov, E., Fischer, R., Beierlein, C., Ramos, A., Verkasalo, M., Lönnqvist, J. E., Demirutku, K., Dirilen-Gumus O. ve Konty, M. (2012). Refining the theory of basic individual values. Journal of Personality and Social Psychology, 103, 663-688.

Schwartz, S. H., Melech, G., Lehmann, A., Burgess, S., Harris, M. ve Owens, V. (2001). Extending the cross-cultural validity of the theory of basic human values with a different method of measurement. Journal of Cross-Cultural Psychology, 32(5), 519-542.

Sesli, Ç. ve Demir Başaran, S. (2016). Ortaöğretim öğrencilerinin değer yönelimleri ve özerklik düzeyleri arasındaki ilişkinin incelenmesi. Mustafa Kemal Üniversitesi Sosyal Bilimler Enstitüsü Dergisi, 13(34), 238-258.

Thompson, R. A., Meyer, S. ve McGinley, M. (2006). Understanding values in relationships: The development of conscience. M. Killen ve J. G. Smetana (Ed.), Handbook of moral development içinde (s. 267-297). Lawrence Erlbaum Associates Publishers.

Tosun, T. (2015). Illkokul birinci sinıfta okuyan çocukların ve annelerinin değer algılarının karşılaştırmalı incelenmesi. (Yayınlanmamış Yüksek Lisans Tezi). Maltepe Üniversitesi, Sosyal Bilimler Enstitüsü, İstanbul. 
Tulviste, T. (2013). Socialization values of mothers and fathers: Does the child's age matter? Trames: A Journal of the Humanities and Social Sciences, 17(2), 129.

Tulviste, T., Kall, K. ve Rämmer, A. (2017). Value priorities of younger and older adults in seven European countries. Social Indicators Research, 133(3), 931-942.

Uzefovsky, F., Döring, A. K. ve Knafo-Noam, A. (2016). Values in middle childhood: Social and genetic contributions. Social Development, 25(3), 482-502.

van Herk, H. ve Poortinga, Y. H. (2012). Current and historical antecedents of individual value differences across 195 regions in Europe. Journal of Cross-Cultural Psychology, 43(8), 1229-1248. 